\title{
Influence of the Reactor Shape on the Kinetics of Ethanol Production in Laboratory-Scale Batch Fermentation Tests Carried out in Unstirred Vessels
}

\author{
Walter Borzani*, Fabiana Saraguza de Souza, Claudia Yoshie Soyama, Patricia Marie \\ Furuko and Daniela Souza Ferreira \\ Instituto Mauá de Tecnologia; Escola de Engenharia Mauá; Praça Mauá 1; 09580-900; borzani@maua.br; São \\ Caetano do Sul - SP - Brasil
}

\begin{abstract}
The influence of the shape of laboratory-scale unstirred reactors on the kinetics of ethanol production in batch ethanol fermentation was studied. Two reactors were used: a 1-L glass measuring cylinder and a 2-L Erlenmeyer flask. The volume of inoculated medium in each reactor was 1,000 $\mathrm{mL}$. The above influence was affected by the ratio between the initial yeast cells concentration $\left(X_{0}: \sim 7 \mathrm{~g} / \mathrm{L}, \sim 14 \mathrm{~g} / \mathrm{L}\right.$, and $\sim 21 \mathrm{~g} / \mathrm{L}$, dry matter) and the initial glucose concentration $\left(S_{0}: \sim 100 \mathrm{~g} / \mathrm{L}, \sim 150 \mathrm{~g} / \mathrm{L}\right.$ and $\left.\sim 200 \mathrm{~g} / \mathrm{L}\right)$. When $X_{0} / S_{0}$ increased from 0.038 to 0.219 the influence of the reactor shape decreased, and was not observed when $X_{0} / S_{0}=0.22$ to 0.24 . The reactor shape practically did not affect the ethanol yield, the final yeast cells concentration and both the viability and the morphology of the cells in tests carried out at the same value of $X_{0} / S_{0}$.
\end{abstract}

Key words: Batch ethanol fermentation; ethanol production kinetics; reactor shape; unstirred reactor

\section{INTRODUCTION}

Due to the difficulty to obtain useful information on the kinetics of fermentation processes from reactors that have spatially nonuniform conditions, it is desirable to study kinetics in reactors that are well mixed (Bailey and Ollis, 1986).

Laboratory-scale fermentation tests, however, are frequently carried out in small unstirred reactors. When gases are produced (e.g. ethanol fermentation, anaerobic treatment of wastewater, acetone-butanol fermentation), the ascending gas bubbles, depending on the experimental conditions, may significantly affect the degree of homogeneity of the fermenting medium and, consequently, the kinetic behavior of the microbial cells. Among the above conditions, the reactor shape must be considered.

Sung and Dague (1995), studying the anaerobic treatment of wastewaters in unstirred reactors, concluded that the performance of the reactors with a ratio height/diameter between 1.8 and 5.6 was better than that of reactors with the above ratio equal to 0.61 to 0.93 . Only one paper was found studying the influence of the shape of unstirred reactors on batch ethanol fermentation. In the above paper, Gómez et al. (1981) reported that the reactor shape significantly affected the time to attain complete fermentation of media prepared from blackstrap molasses. No information was found reporting the influence of the reactor shape on batch acetone-butanol fermentation.

\footnotetext{
${ }^{*}$ Author for correspondence
} 
Such facts clearly show that the reactor shape must be considered mainly to compare the kinetic results obtained in different experiments.

The aim of this work was to study the influence of the shape of laboratory-scale unstirred reactors on the kinetics of ethanol fermentation.

\section{MATERIALS AND METHODS}

Baker's compressed yeast (Sacharomyces cerevisiae) was used as inoculum in all the experiments. Tests were carried out with initial yeast concentrations (dry matter) approximately equal to $7 \mathrm{~g} / \mathrm{L}, 14 \mathrm{~g} / \mathrm{L}$ and $21 \mathrm{~g} / \mathrm{L}$.

The fermentation media were prepared dissolving D-glucose, $\mathrm{KH}_{2} \mathrm{PO}_{4}$, urea, yeast extract and $\mathrm{MgSO}_{4} .7 \mathrm{H}_{2} \mathrm{O}$ in distilled water. The initial glucose concentrations of the inoculated media were approximately equal to $100 \mathrm{~g} / \mathrm{L}, 150 \mathrm{~g} / \mathrm{L}$ and 200 $\mathrm{g} / \mathrm{L}$. The initial concentrations of the other nutrients (\% of the initial glucose concentration) were: $\mathrm{KH}_{2} \mathrm{PO}_{4}, 4.00$; urea, 1.75; yeast extract, $1.75 ; \mathrm{MgSO}_{4} .7 \mathrm{H}_{2} \mathrm{O}, 0.75$. The initial $\mathrm{pH}$ of the inoculated media was 4.5. No antifoam was used, since very small quantities of foam were produced. The reactors used in this work were 1-L glass measuring cylinders and 2-L Erlenmeyer flasks. With the only purpose to assure the same evaporation losses in both reactors, the cover schematically represented in Fig. 1 was placed on the cylinder. The above reactor shapes were chosen because they are the most frequently used to carry out ethanol fermentation laboratory-scale experiments. Each reactor received $1,000 \mathrm{~mL}$ of inoculated media, leading to $H / D(H=$ height of the medium layer; $D=$ average reactor diameter) equal to 6.3 and 0.46 in the cylinder and in the Erlenmeyer flask, respectively. The tests were carried out at $32 \pm 1^{\circ} \mathrm{C}$. The rectors were not stirred and no air was supplied.

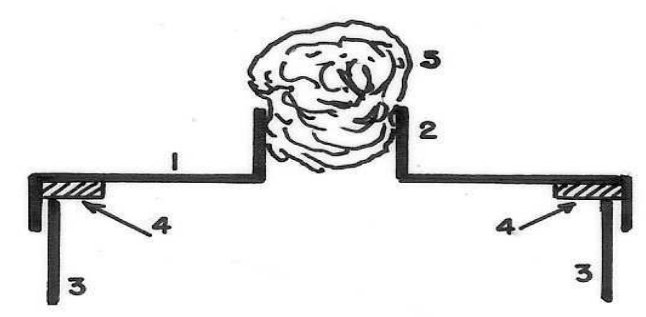

Figure 1 - Schematic representation of the cover placed on the cylinder. 1: metallic cover. 2: cover neck dimensionally equal to the Erlenmeyer flask neck. 3: reactor wall. 4: rubber gasket. 5: cotton wool plug (4.5g).

The DNS method (Miller, 1959), dichromate method (Joslyn, 1970) and the method described by Borzani et al. (1977) were used to measure the concentrations of glucose, ethanol and yeast cells, respectively. The yeast cells viability was measured by the methylene blue staining method (Vairo, 1961).

The relative ethanol yield $(\eta)$ and the ethanol productivity $(P)$ were calculated by Equations [1] and [2], respectively, where $E_{p}$ is the concentration of produced ethanol, $S_{0}$ is the initial glucose concentration, $t_{f}$ is the time to attain complete fermentation and 0.511 is the stoichiometric ratio between ethanol and glucose.

$$
\begin{gathered}
\eta=\frac{100 E_{p}}{0.511 S_{0}} \\
P=\frac{E_{p}}{t_{f}}
\end{gathered}
$$

The ethanol production rates $(d E / d t)$ were calculated by the numerical differentiation method (Sinclair and Cantero, 1990). 


\section{RESULTS}

Fig. 2, where $E$ is the ethanol concentration at time $t$, shows the results obtained in a typical experiment.

Table 1 , where $X_{0}$ and $X_{f}$ are the initial and the final yeast cells concentrations (dry matter) respectively, shows the results obtained in our tests. The final concentrations of glucose were smaller than $1 \%$ of $S_{0}$.
Figs. (3), (4) and (5) present the influence of both $X_{0} / S_{0}$ and the reactor shape on the ethanol production rates.

The yeast cells viability at the end of the experiments carried out in the cylinder and in the Erlenmeyer flask varied from $77 \%$ to $85 \%$ and from $83 \%$ to $89 \%$; respectively. The cells viability of the inocula was $97-99 \%$. The yeast cells morphology was not affected by the reactor shape.

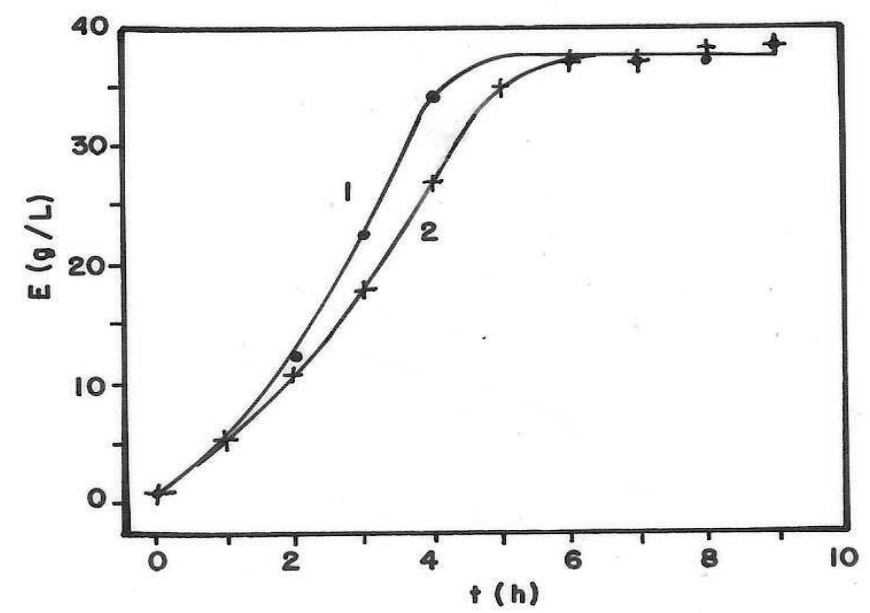

Figure 2 - Ethanol concentrations $(E)$ during tests carried out using the same medium $\left(S_{0}=96.8\right.$ $\mathrm{g} / \mathrm{L} ; X_{0} / S_{0}=0.062$ ) in a $1-\mathrm{L}$ glass measuring cylinder (Curve 1 ; Test $\mathrm{N}^{\circ} 1$ ) and in a $2-\mathrm{L}$ Erlenmeyer flask (Curve 2; Test $\mathrm{N}^{\circ}$ 2). See Table 1.

Table 1 - Results obtained in all the tests.

\begin{tabular}{cccccccccc}
\hline $\begin{array}{c}\text { Test } \\
\mathbf{N}^{\mathbf{0}}\end{array}$ & $\begin{array}{c}\text { Reactor } \\
(*)\end{array}$ & $\begin{array}{c}\boldsymbol{S}_{\boldsymbol{0}} \\
(\mathbf{g} / \mathbf{L})\end{array}$ & $\begin{array}{c}\boldsymbol{X}_{\boldsymbol{0}} \\
(\mathbf{g} / \mathbf{L})\end{array}$ & $\begin{array}{c}\boldsymbol{X}_{f} \\
(\mathbf{g} / \mathbf{L})\end{array}$ & $\boldsymbol{X}_{\boldsymbol{0}} / \boldsymbol{S}_{\boldsymbol{o}}$ & $\begin{array}{c}\boldsymbol{t}_{\boldsymbol{f}} \\
(\mathbf{h})\end{array}$ & $\begin{array}{c}\boldsymbol{E}_{\boldsymbol{p}} \\
(\mathbf{g} / \mathbf{L})\end{array}$ & $\begin{array}{c}\boldsymbol{P} \\
(\mathbf{g} / \mathbf{L} \mathbf{h})\end{array}$ & $\begin{array}{c}\boldsymbol{\eta} \\
(\boldsymbol{\%})\end{array}$ \\
\hline 1 & Cyl. & 96.8 & 6.0 & 14.2 & 0.062 & 5.0 & 36.5 & 7.3 & 73.8 \\
2 & Erl. & 96.8 & 6.0 & 14.7 & 0.062 & 6.0 & 36.5 & 6.1 & 73.8 \\
3 & Cyl. & 97.0 & 13.5 & 20.1 & 0.139 & 3.5 & 34.2 & 9.8 & 69.0 \\
4 & Erl. & 97.0 & 13.5 & 20.6 & 0.139 & 4.0 & 33.9 & 8.5 & 68.4 \\
5 & Cyl. & 97.0 & 21.2 & 23.2 & 0.219 & 2.5 & 31.6 & 12.6 & 63.7 \\
6 & Erl. & 97.0 & 21.2 & 26.2 & 0.219 & 2.5 & 31.6 & 12.6 & 63.7 \\
7 & Cyl. & 156.8 & 7.6 & 13.5 & 0.048 & 9.0 & 60.5 & 6.7 & 75.5 \\
8 & Erl. & 156.8 & 7.6 & 11.9 & 0.048 & 11.0 & 58.1 & 5.3 & 72.5 \\
9 & Cyl. & 148.7 & 14.5 & 21.2 & 0.097 & 4.0 & 58.0 & 14.5 & 76.3 \\
10 & Erl. & 148.7 & 14.5 & 19.0 & 0.097 & 5.0 & 57.7 & 11.5 & 75.9 \\
11 & Cyl. & 149.2 & 21.3 & 30.2 & 0.143 & 4.0 & 57.2 & 14.3 & 75.0 \\
12 & Erl. & 149.2 & 21.3 & 29.4 & 0.143 & 5.0 & 58.7 & 11.7 & 77.0 \\
13 & Cyl. & 198.6 & 7.6 & 9.6 & 0.038 & 10.0 & 80.6 & 8.1 & 79.4 \\
14 & Erl. & 198.6 & 7.6 & 11.9 & 0.038 & 13.0 & 80.2 & 6.2 & 79.0 \\
15 & Cyl. & 187.2 & 13.8 & 21.2 & 0.074 & 7.0 & 79.0 & 11.3 & 82.6 \\
16 & Erl. & 187.2 & 13.8 & 16.6 & 0.074 & 9.0 & 78.4 & 8.7 & 82.0 \\
17 & Cyl. & 198.2 & 21.4 & 23.7 & 0.108 & 6.0 & 73.2 & 12.2 & 72.3 \\
18 & Erl. & 198.2 & 21.4 & 24.1 & 0.108 & 7.0 & 74.4 & 10.6 & 73.5 \\
\hline
\end{tabular}

(*) Cyl.: Cylinder $\quad$ Erl.: Erlenmeyer flask 


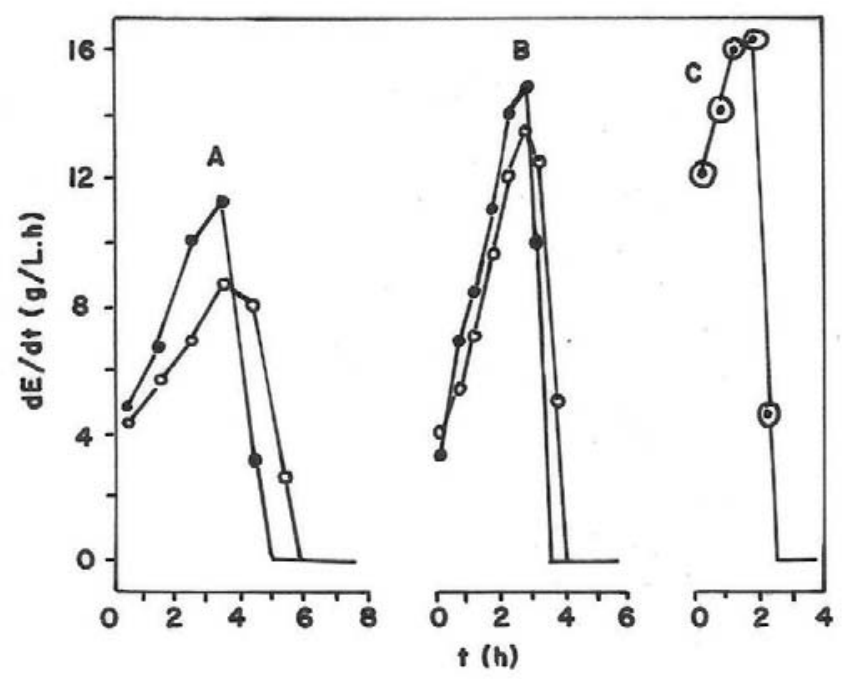

Figure 3 - Influence of both the reactor shape (Cylinder, $\bullet$; Erlenmeyer flask, o) and $X_{0} / S_{0}$ on the ethanol production rate $(d E / d t)$ when $\mathrm{S}_{0} \cong 100 \mathrm{~g} / \mathrm{L}$. A: tests $\mathrm{n}^{\circ} 1$ and $2\left(X_{0} / S_{0}=0.062\right)$. B: tests $n^{\circ} 3$ and $4\left(X_{0} / S_{0}=0.139\right)$. C: tests $n^{\circ} 5$ and $6\left(X_{0} / S_{0}=0.219\right)$. See Table 1.

\section{DISCUSSION}

During batch ethanol fermentation experiments carried out in unstirred reactors, the frequency of the contacts between the yeast cells and the molecules of the substances dissolved in the medium, depends on both the $\mathrm{CO}_{2}$ production rates (mainly affected by the concentrations of glucose and yeast cells) and the velocities of the ascending $\mathrm{CO}_{2}$ bubbles (affected by both the $\mathrm{CO}_{2}$ production rates and the reactor shape).
When media with the same composition are fermented in the cylinder and in the Erlenmeyer flask, the $\mathrm{CO}_{2}$ will be produced at the same rate at the beginning of the test, but the velocities of the ascending gas bubbles in the cylinder will be greater than in the Erlenmeyer flask. If the $\mathrm{CO}_{2}$ production rate is sufficiently high, the yeast cells will be maintained in suspension in both reactors leading to practically the same kinetic results (see Fig. 3,C).

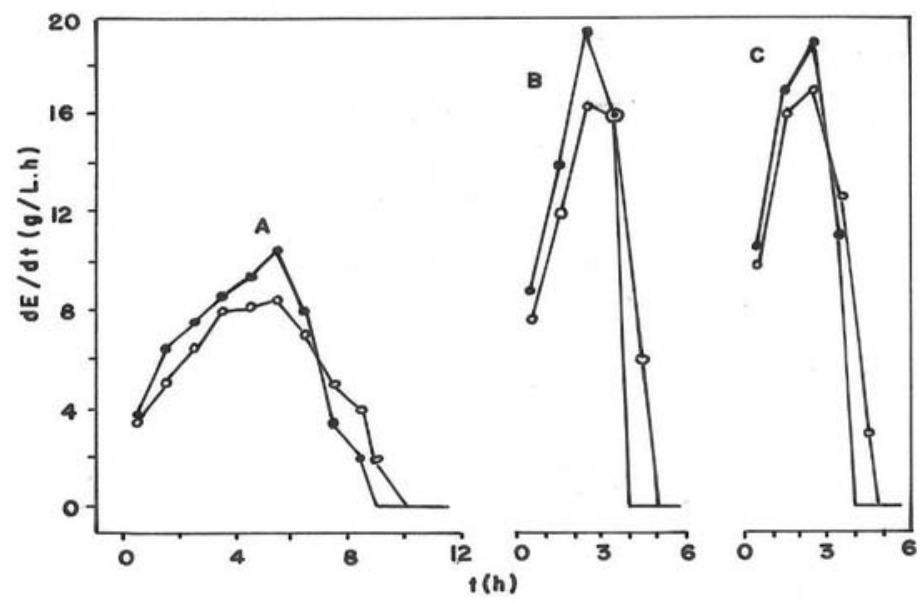

Figure 4 - Influence of both the reactor shape (Cylinder, $\bullet$; Erlenmeyer flask, o) and $X_{0} / S_{0}$ on the ethanol production rate $(d E / d t)$ when $\mathrm{S}_{0} \cong 150 \mathrm{~g} / \mathrm{L}$. A: tests $\mathrm{n}^{\circ} 7$ and $8\left(X_{0} / S_{0}=0.048\right)$. B: tests $n^{\circ} 9$ and $10\left(\mathrm{X}_{0} / \mathrm{S}_{0}=0.097\right) . \mathrm{C}$ : tests $\mathrm{n}^{\circ} 11$ and $12\left(\mathrm{X}_{0} / \mathrm{S}_{0}=0.143\right)$. See Table 1. 


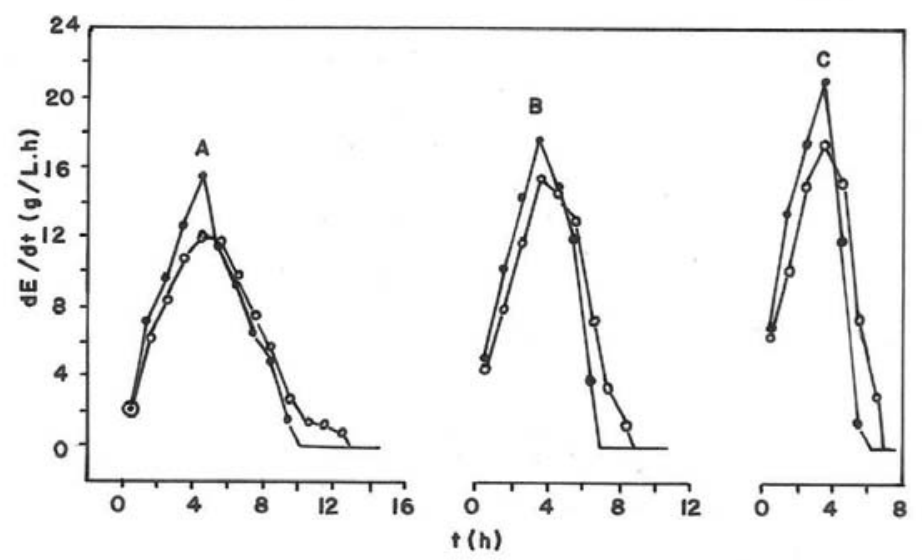

Figure 5 - Influence of both the reactor shape (Cylinder, •; Erlenmeyer flask, o) and $X_{0} / S_{0}$ on the ethanol production rate $(d E / d t)$ when $\mathrm{S}_{0} \cong 200 \mathrm{~g} / \mathrm{L}$. A: tests $\mathrm{n}^{\circ} 13$ and $14\left(X_{0} / S_{0}=0.038\right)$. B: tests $n^{\circ} 15$ and $16\left(X_{0} / S_{0}=0.074\right)$. C: tests $n^{\circ} 17$ and $18\left(X_{0} / S_{0}=0.108\right)$. See Table 1.

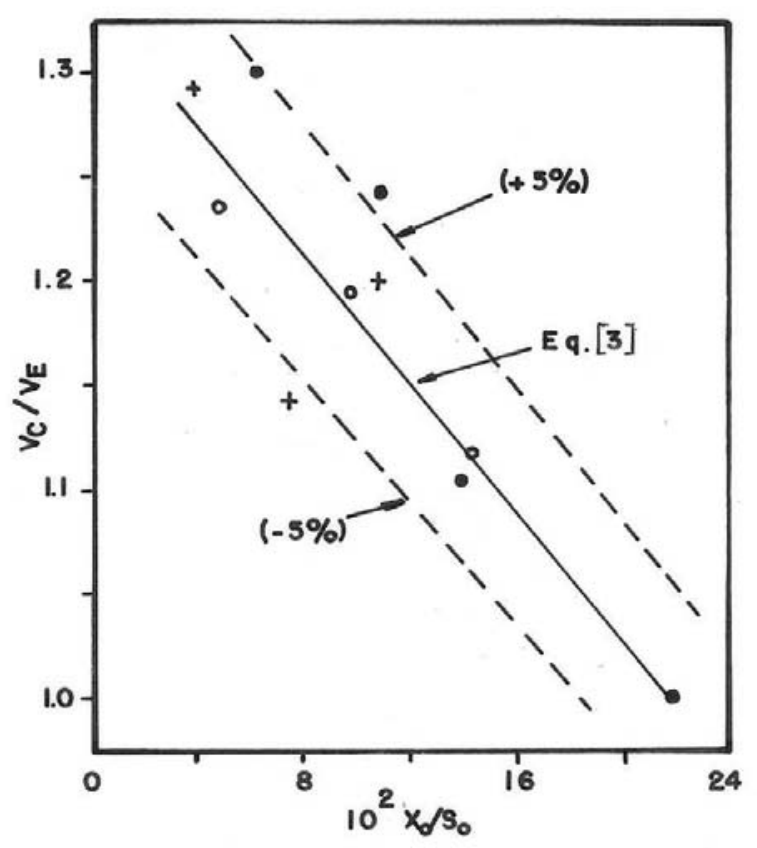

Figure 6 - Influence of $X_{0} / S_{0}$ on $V_{C} / V_{E}$. Initial glucose concentration: $\sim 100 \mathrm{~g} / \mathrm{L}(\bullet), \sim 150 \mathrm{~g} / \mathrm{L}$ (o) and $\sim 200 \mathrm{~g} / \mathrm{L}(+)$.

If, however, the $\mathrm{CO}_{2}$ production rate is relatively small, the yeast cells will tend to settle faster in the Erlenmeyer flask than in the cylinder. In this last case, the fermentation will be more rapid in the cylinder leading to shorter fermentation times and greater ethanol productivities (See Appendix).

Otherwise, it must be pointed out that a batch fermentation, even in well mixed reactors, is not a 
steady-state process, that is, the glucose and cells concentrations, as well as the $\mathrm{CO}_{2}$ production rate, the number, diameters and velocities of the ascending $\mathrm{CO}_{2}$ bubbles (whose measurement is presently unfeasible), vary from time to time. Consequently, it is very difficult (perhaps impossible) to propose theoretical correlations between the obtained kinetic results and the actual experimental conditions, since such conditions change as fermentation proceeds. Borzani et al. (1993), however, reported that the time necessary to complete the batch ethanol fermentation may be calculated by $K\left(S_{O} / X_{O}\right)^{\alpha}$, where $K(K>1)$ and $\alpha$ $(0<\alpha<1)$ depend on the experimental conditions. In other words, the above time decreases, and consequently the $\mathrm{CO}_{2}$ production rate increases, when $X_{0} / S_{0}$ increases. Based on the above fact, the ratio $X_{0} / S_{0}$ was assumed as a reference parameter to discuss the experimental results, leading to several empirical and practical consequences.

Fig. 6 where $V_{C}$ and $V_{E}$ are, respectively, the maxima values of $d E / d t$ in tests carried out in the cylinder and in the Erlenmeyer flask for the same value of $X_{0} / S_{0}$, show how $X_{0} / S_{0}$ affects $V_{C} / V_{E}$. Equation [3] is also represented in Fig. $6(r=$ correlation coefficient).

$$
\begin{gathered}
\frac{V_{C}}{V_{E}}=1.33-1.425 \frac{X_{0}}{S_{0}} \\
(r=-0.882)
\end{gathered}
$$

Calling $t_{f C}$ and $t_{f E}$, respectively, the complete fermentation times in tests carried out in the cylinder and in the Erlenmeyer flask for the same value of $X_{0} / S_{0}$, Figs. 7 and 8 show, respectively, the correlation between $t_{f E}$ and $t_{f C}$ (see Equation [4]) and the correlation between $t_{f E}-t_{f C}$ and $X_{0} / S_{0}$ (see Equation [5]).

$$
\begin{gathered}
t_{f E}=-0.62+1.335 t_{f C} \\
(r=0.996) \\
t_{f E}-t_{f_{C}}=1.02 \frac{0.219-\left(X_{0} / S_{0}\right)}{0.021+\left(X_{0} / S_{0}\right)} \\
(r=0.985)
\end{gathered}
$$

Fig. 9, where $E_{p C}$ and $E_{p E}$ are, respectively, the concentrations of produced ethanol in tests carried out in the cylinder and in the Erlenmeyer flask for the same value of $S_{0} / \mathrm{X}_{0}$, clearly shows that the shape of the flask practically did not affect the quantity of produced ethanol. Obviously, the same conclusion was reached regarding the relative ethanol yield.

Calling $P_{C}$ and $P_{E}$ the ethanol productivities in tests carried out in the cylinder and in the Erlenmeyer flask, respectively, for the same value of $S_{0} / X_{0}$, Fig. 10 shows the correlation between $P_{C} / P_{E}$ and $S_{0} / X_{0}$ (see equation [6]).

$$
\begin{aligned}
\frac{P_{C}}{P_{E}} & =1.356-1.457 \frac{X_{0}}{S_{0}} \\
\quad(r & =-0.864)
\end{aligned}
$$




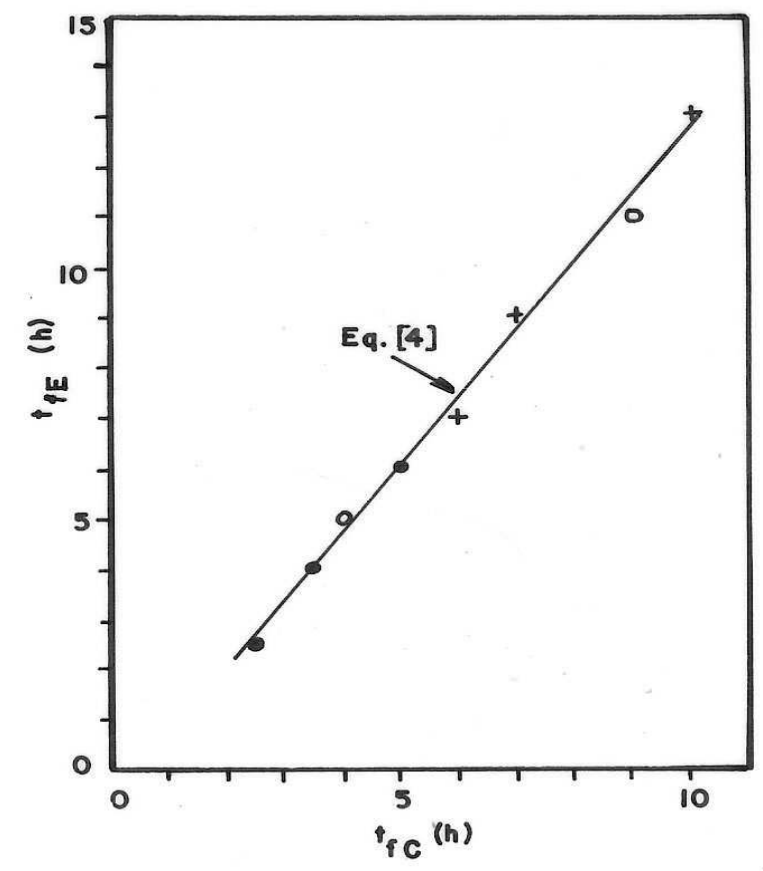

Figure 7 - Correlation between $\mathrm{t}_{\mathrm{fE}}$ and $\mathrm{t}_{\mathrm{fC}}$. Initial glucose concentration: $\sim 100 \mathrm{~g} / \mathrm{L}(\bullet), \sim 150 \mathrm{~g} / \mathrm{L}(\mathrm{o})$ and $\sim 200 \mathrm{~g} / \mathrm{L}(+)$.

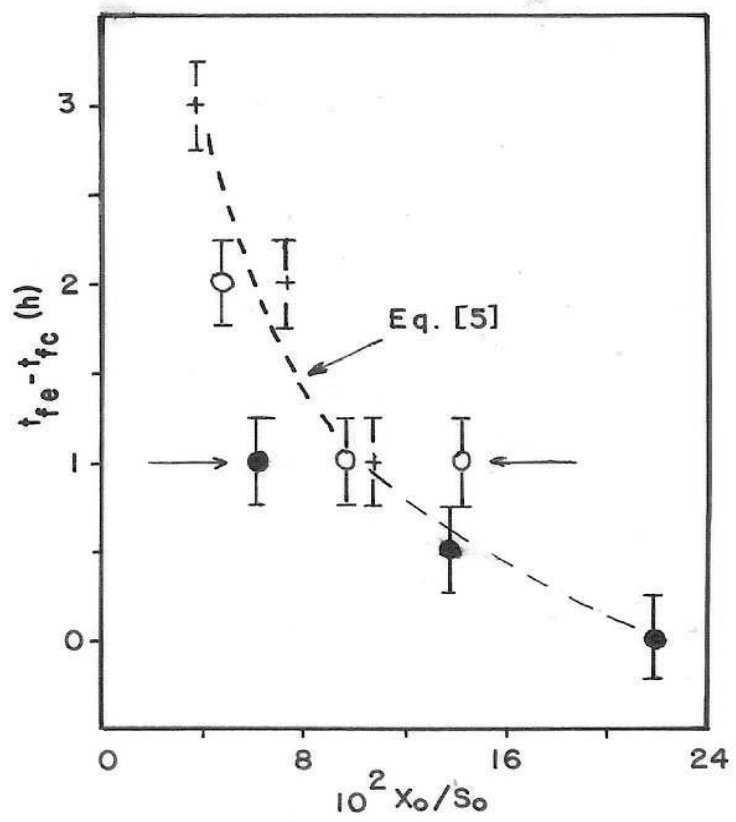

Figure 8 - Influence of $X_{0} / S_{0}$ on $t_{f E}-t_{f C}$. Initial glucose concentration: $\sim 100 \mathrm{~g} / \mathrm{L}(\bullet), \sim 150 \mathrm{~g} / \mathrm{L}$ (o) and $\sim 200 \mathrm{~g} / \mathrm{L}(+)$. The points indicated by arrows were not considered to obtain Equation [5]. 


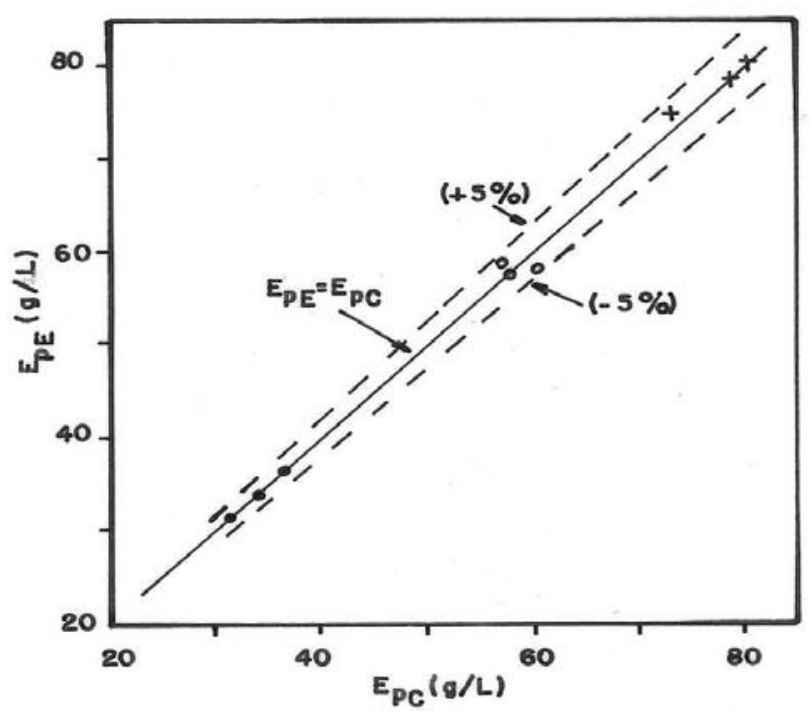

Figure 9 - Correlation between $E_{p E}$ and $E_{p C}$. Initial glucose concentration: $\sim 100 \mathrm{~g} / \mathrm{L}(\bullet), \sim 150 \mathrm{~g} / \mathrm{L}$ (o) and $\sim 200 \mathrm{~g} / \mathrm{L}(+)$.

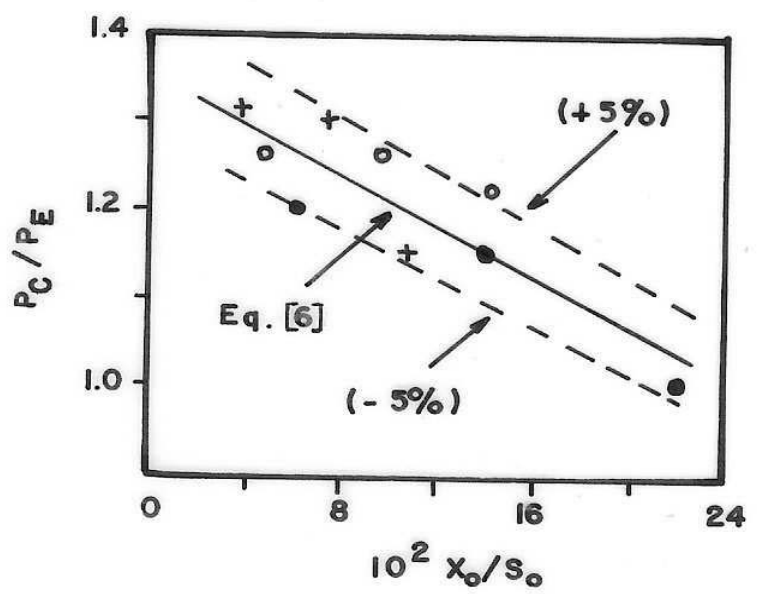

Figure 10 - Influence of $X_{0} / S_{0}$ on $P_{C} / P_{E}$. Initial glucose concentration: $\sim 100 \mathrm{~g} / \mathrm{L}(\bullet), \sim 150 \mathrm{~g} / \mathrm{L}(\mathrm{o})$ and $\sim 200 \mathrm{~g} / \mathrm{L}(+)$.

Fig. 11, where $X_{f C}$ and $X_{f E}$ are, respectively, the final yeast cells concentrations in tests carried out in the cylinder and in the Erlenmeyer flask for the same value of $X_{0} / S_{0}$, seems to indicate that there is no systematic and significant influence of the reactor shape on the yeast cells final concentrations.

Figs. 3 to 8 and 10 clearly show that the influence of the reactor shape on the kinetics of the ethanol production decreased when $X_{0} / S_{0}$ increased. In the particular case of the tests carried out with $S_{0} \cong 100$ $g / L$, the above influence disappeared when $X_{0} / S_{0}=0.219$ (see Fig. 3).

Otherwise, the empirical Equations [3] and [6] permit to calculate $X_{0} / S_{0}$ when $V_{c}=V_{E}$ and $P_{c}=P_{E}$, respectively, i.e., the values of $X_{0} / S_{0}$ corresponding to an experimental condition where the reactor shape would not affect the process kinetics. The above values of $X_{0} / S_{0}$ calculated by Equations [3] and [6] were 0.234 and 0.244 , respectively. 
Table 2 - Results obtained in the additional tests.

\begin{tabular}{|c|c|c|c|c|c|c|c|}
\hline $\begin{array}{c}S_{0} \\
(\mathrm{~g} / \mathrm{L})\end{array}$ & $\begin{array}{c}X_{0} \\
(\mathrm{~g} / \mathrm{L})\end{array}$ & $X_{0} / S_{0}$ & $\begin{array}{c}\text { Reactor } \\
(*)\end{array}$ & $\begin{array}{c}t_{f} \\
(\mathbf{h})\end{array}$ & $\begin{array}{c}E_{p} \\
(\mathrm{~g} / \mathrm{L})\end{array}$ & $\underset{(\mathrm{g} / \mathrm{L} \cdot \mathbf{h})}{P}$ & $\begin{array}{c}\eta \\
(\%)\end{array}$ \\
\hline 150 & 32.0 & 0.213 & $\begin{array}{l}\text { Cyl. } \\
\text { Erl. }\end{array}$ & $\begin{array}{l}2.5 \\
2.7\end{array}$ & $\begin{array}{l}58.6 \\
60.5\end{array}$ & $\begin{array}{l}23.4 \\
22.4\end{array}$ & $\begin{array}{l}76.4 \\
78.9\end{array}$ \\
\hline 200 & 43.2 & 0.216 & $\begin{array}{l}\text { Cyl. } \\
\text { Erl. }\end{array}$ & $\begin{array}{l}3.5 \\
4.0\end{array}$ & $\begin{array}{l}56.1 \\
56.4\end{array}$ & $\begin{array}{l}19.1 \\
17.1\end{array}$ & $\begin{array}{l}65.4 \\
66.9\end{array}$ \\
\hline
\end{tabular}

(*) Cyl.: Cylinder $\quad$ Erl: Erlenmeyer flask

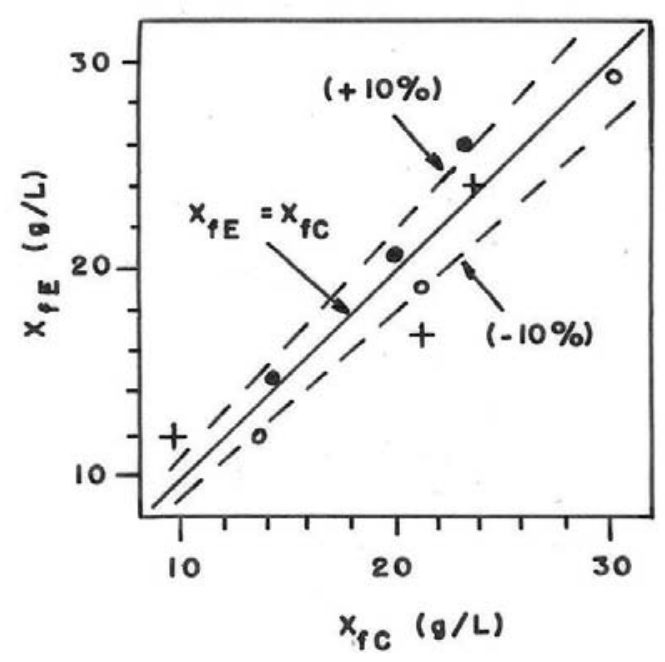

Figure 11 - Correlation between $\mathrm{X}_{\mathrm{fE}}$ and $\mathrm{X}_{\mathrm{fC}}$. Initial glucose concentration: 100 g/L $(\bullet), \sim 150 \mathrm{~g} / \mathrm{L}$ (o) and $\sim 200 \mathrm{~g} / \mathrm{L}(+)$.

The average of the $X_{0} / S_{0}$ values cited above $(0.219,0.234$ and 0.244$)$ is 0.232 (standard deviation, 0.013).

Assuming $X_{0} / S_{0}=0.232$, Equation [5] leads to $t_{f E}$ $-t_{f C}=-3.1 \mathrm{~min}$, i.e., considering the uncertainties associated with the evaluations of $t_{f E}$ and $t_{f C}, t_{f E}=$ $t_{f c}$.

We may then conclude that the reactor shape affected the ethanol production kinetics when $X_{0} / S_{0}$ was smaller than 0.22 to 0.24 .

Considering that with $S_{0}$ approximately equal to $150 \mathrm{~g} / \mathrm{L}$ and $200 \mathrm{~g} / \mathrm{L}$ the maximum values of $X_{0} / S_{0}$ were 0.143 and 0.108 , respectively, two sets of additional tests were carried out with the only purpose to confirm the conclusions cited above. The results obtained in such tests (see Table 2) are in accordance with the results presented in Figs. 7 to 10 .

The evolved $\mathrm{CO}_{2}$ was not measured. Otherwise, considering that the mass of produced $\mathrm{CO}_{2}$ is practically proportional to the mass of produced ethanol, the influence of $X_{0} / S_{0}$ on the $\mathrm{CO}_{2}$ productivity would be represented by an Equation similar to Equation [6].

It seems advisable to point out that the results presented in this paper could be important mainly when the purpose is to compare kinetic parameters calculated from different batch ethanol experiments carried out in unstirred reactors. In this case, depending on the value of $X_{0} / S_{0}$, the reactor shape could significantly affect the values of the above parameters. Otherwise, the cells morphology, cells viability, quantity of the produced cells and the relative ethanol yield were pratically not affected by the reactor shape.

Obviously, the equations presented in this paper cannot be applied to laboratory-scale tests carried out under other experimental conditions and also to industrial reactors, since in this case the fedbatch technique is used. 


\section{APPENDIX}

The $\mathrm{CO}_{2}$ production rates and the velocities of the ascending $\mathrm{CO}_{2}$ bubbles were previously assumed as the causes of the obtained kinetic results (see DISCUSSION and Figs. 3 to 5). The calculation (or the measument) of the velocities of the ascending $\mathrm{CO}_{2}$ bubbles, however, is presently impossible.

Otherwise, when the calculation of the actual flow velocities is unfeasable (e.g. the flow of gases through a porous membrane and the flow of liquids through a fixed bed), the superficial velocities are usually considered as the flow parameters. The superficial velocities of the evolved $\mathrm{CO}_{2}$ were then calculated.

The above calculation was carried out considering the following values: a) volume of fermenting medium, 1L (see MATERIALS AND METHODS); b) ratio between the mass of produced $\mathrm{CO}_{2}$ and the mass of produced ethanol, $0.955 \mathrm{~g} / \mathrm{g}$; c) specific volume of the $\mathrm{CO}_{2}$ at the experimental conditions (temperature, $32^{\circ} \mathrm{C}$; atmospheric pressure, $\left.9.33 \cdot 10^{4} \mathrm{~Pa}\right), 617 \mathrm{~mL} / \mathrm{g}$; d) cylinder diameter,

$5.9 \mathrm{~cm}$; e) Erlenmeyer flask average diameter (considering only the portion containing the fermenting medium), $14.0 \mathrm{~cm}$.

Equations [1-A] and [2-A] permitted to calculate the superficial velocity (measured in $\mathrm{cm} / \mathrm{min}$ ) of the evolved $\mathrm{CO}_{2}$ at time $t(R)$ and the average superficial velocity of the evolved $\mathrm{CO}_{2}\left(R_{a v}\right)$, respectively.

$$
\begin{aligned}
& R=\frac{12.5}{D^{2}} \cdot \frac{d E}{d t} \\
& R_{a v}=\frac{12.5}{D^{2}} \cdot \frac{E_{p}}{t_{f}}
\end{aligned}
$$

The values of $R$ were calculated at $t=0.5 h$, since the produced $\mathrm{CO}_{2}$ evolves after saturating the fermenting medium. Table 1-A shows the calculated values o $R$ at $t=0.5 h$ and $R_{a v}$.

Table 1-A - Calculated values of the superficial velocity at $t=0.5 h(R)$ and of the average superficial velocity $\left(R_{a v}\right)$ of the evolved $\mathrm{CO} 2$.

\begin{tabular}{ccc} 
Test & $\begin{array}{c}\boldsymbol{R}(\mathbf{a t} \boldsymbol{t}=\mathbf{0 . 5 h}) \\
(\mathbf{c m} / \mathbf{m i n})\end{array}$ & $\begin{array}{c}\boldsymbol{R}_{\boldsymbol{a v}} \\
\mathbf{N}^{\circ}\end{array}$ \\
\hline $\mathbf{c m} / \mathbf{m i n})$
\end{tabular}

Figs. 3 to 5 show that only Tests $\mathrm{N}^{\circ} 5$ (cylinder) and $\mathrm{N}^{\circ} 6$ (Erlenmeyer flask), carried out using the same inoculated medium (see Table1), led to identical results. It is then possible to conclude that $R=0.76 \mathrm{~cm} / \mathrm{min}$ (at $t=0.5 \mathrm{~h}$ ), or $R_{a v}=0.81$ $\mathrm{cm} / \mathrm{min}$, were sufficiently high to maintain all the yeast cells suspended in the medium.

Otherwise, Table 1-A also shows that: a) all the values $R$ (at $t=0.5 \mathrm{~h}$ ) and all the values of $R_{a v}$ of the tests carried out in cylinders were higher then, respectively, $0.76 \mathrm{~cm} / \mathrm{min}$ and $0.81 \mathrm{~cm} / \mathrm{min}$; b) 
excluding Test $\mathrm{N}^{\circ} 6$, the values $R$ (at $t=0.5 h$ ) and $R_{a v}$ of the tests carried out in Erlenmeyer flasks are smaller than $0.76 \mathrm{~cm} / \mathrm{min}$ and $0.81 \mathrm{~cm} / \mathrm{min}$, respectively.

The above results permit to say that the assumption presented at the DISCUSSION is acceptable.

\section{ACKNOWLEDGMENTS}

The authors acknowledge the technical assistance of Douglas Dalla Justina and Renato Piplovic.

\section{NOMENCLATURE}

$d E / d t$ ethanol production rate $(\mathrm{g} / \mathrm{L} . \mathrm{h})$

$D$ reactor internal diameter $(\mathrm{cm})$

$E \quad$ ethanol concentration $(\mathrm{g} / \mathrm{L})$

$E_{p} \quad$ produced ethanol concentration $(\mathrm{g} / \mathrm{L}) E_{p C}$ value of $E_{p}$ in test carried out in the cylinder $(\mathrm{g} / \mathrm{L})$

$E_{p E} \quad$ value of $E_{p}$ in test carried out in the Erlenmeyer flask (g/L)

$H \quad$ height of the medium layer $(\mathrm{cm})$

$P \quad$ ethanol productivity (g/L.h)

$P_{C} \quad$ value of $P$ in test carried out in the cylinder (g/L.h)

$P_{E} \quad$ value of $P$ in test carried out in the Erlenmeyer flask (g/L.h)

$r \quad$ correlation coefficient

$R \quad$ superficial velocity of the evolved $\mathrm{CO}_{2}$ $(\mathrm{cm} / \mathrm{min})$

$R_{a v} \quad$ average superficial velocity of the evolved $\mathrm{CO}_{2}(\mathrm{~cm} / \mathrm{min})$

$S_{0} \quad$ initial glucose concentration $(\mathrm{g} / \mathrm{L})$

$t \quad$ time (h)

$t_{f} \quad$ value of $t$ to attain complete fermentation (h)

$t_{f C} \quad$ value of $t_{f}$ in test carried out in the cylinder (h)

$t_{f E} \quad$ value of $t_{f}$ in test carried out in the Erlenmeyer flask (h)

$V_{C} \quad$ maximum value of $d E / d t$ in test carried out in the cylinder (g/L.h)

$V_{E} \quad$ maximum value of $d E / d t$ in test carried out in the Erlenmeyer flask (g/L.h)

$X_{0} \quad$ initial yeast cells concentration (dry matter) $(\mathrm{g} / \mathrm{L})$

$X_{f} \quad$ final yeast cells concentration (dry matter) $(\mathrm{g} / \mathrm{L})$
$X_{f C} \quad$ value of $X_{f}$ in test carried out in the cylinder $(\mathrm{g} / \mathrm{L})$

$X_{f E} \quad$ value of $X_{f}$ in test carried out in the Erlenmeyer flask $(\mathrm{g} / \mathrm{L})$

$\eta \quad$ relative ethanol yield (\%)

\section{RESUMO}

Estudou-se a influência da geometria de reatores não agitados na cinética de produção de etanol em experimentos de fermentação alcoólica realizados por processo descontínuo em escala de laboratório. Foram utilizados dois reatores: um cilindro graduado de $1 \mathrm{~L}$ e um frasco de Erlenmeyer de 2 L. Cada reator operou com $1000 \mathrm{~mL}$ de meio inoculado. A influência da geometria do reator foi afetada pela relação entre a concentração inicial de levedura $\left(X_{0}: \sim 7 \mathrm{~g} / \mathrm{L}, \sim 14 \mathrm{~g} / \mathrm{L}, \mathrm{e} \sim 21 \mathrm{~g} / \mathrm{L}\right.$, matéria seca) e a concentração inicial de glicose $\left(S_{0}: \sim 100\right.$ $\mathrm{g} / \mathrm{L}, \sim 150 \mathrm{~g} / \mathrm{L}$ e $\sim 200 \mathrm{~g} / \mathrm{L})$. A influência da geometria do reator diminuiu quando $\mathrm{X}_{0} / \mathrm{S}_{0}$ aumentou de 0,038 a 0,219 , tornando-se nula para $\mathrm{X}_{0} / \mathrm{S}_{0}=0,22$ a 0,24 . A geometria do reator praticamente não afetou tanto o rendimento em etanol e a concentração final de levedura quanto a viabilidade e a morfologia das células em experimentos com o mesmo valor de $\mathrm{X}_{0} / \mathrm{S}_{0}$.

\section{REFERENCES}

Bailey, J. A. and Ollis, D. F. (1986), Biochemical Engineering Fundamentals. New York: McGraw-Hill Book Company.

Borzani, W.; Gerab, A.; Higuera, G. A. D. L.; Pires, M. H. and Piplovic, R. (1993), Batch ethanol fermentation of molasses:a correlation between the time necessary to complete the fermentation and the initial concentrations of sugar and yeast cells. World J. Microbiol. Biotechnol., 9, 265-268.

Borzani, W.; Gregori, R. E. and Vairo, M. L. R. (1977), Some observations on oscillatory changes in the growth rate of Saccharomyces cerevisiae in aerobic continuous undisturbed culture. Biotechnol. Bioeng., 19, 1363-1374.

Gómez, E. I. V.; Vairo, M. L. R. and Borzani, W. (1981), Influência da geometria do fermentador no andamento de fermentações alcoólicas. Arq. Biol. Tecnol., 24, 361-366.

Joslyn, M. A. (1970), Methods in Food Analysis. New York: Academic Press. 
Miller, G. L. (1959), Use of dinitrosalicylic acid for determination of reducing sugars. Anal. Chem., 31, 426-428.

Sinclair, C. G. and Cantero, D. (1990), Fermentation modeling. In: McNeil, B. and Harvey, L. M. (Eds.). Fermentation: a pratical approach. Oxford: IRL Press.

Sung, S. and Dague, R. R. (1995), Laboratory studies on anaerobic sequencing batch reactor. Water Environ. Res., 67, 294-301.

Vairo, M. L. R. (1961). Methylene blue solutions for staining dead yeast cells. Stain Technol., 36, 329-330.

Received: December 14, 2004; Revised: August 30, 2005; Accepted: February 09, 2006. 